\title{
Analysis and Identification of Flavanoids and Phenolcarbonic Acid in Extract Plant of Clinopodium vulgare
}

\author{
Mokoko Jean Bruno ${ }^{*}$, D. Onreshkova², S. Simeonov², E. Naidenova², I. Pencheva² \\ ${ }^{1}$ Faculty of Health Sciences, Marien Ngouabi University, Brazzaville, Congo \\ ${ }^{2}$ Institute of Pharmacology and Pharmacy, Sofia, Bulgaria \\ Email: ${ }^{\star j b m o k o k o @ y a h o o . f r ~}$
}

How to cite this paper: Bruno, M.J., Onreshkova, D., Simeonov, S., Naidenova, E. and Pencheva, I. (2019) Analysis and Identification of Flavanoids and Phenolcarbonic Acid in Extract Plant of Clinopodium vulgare. American Journal of Analytical Chemistry, 10, 641-646.

https://doi.org/10.4236/ajac.2019.1012045

Received: October 18, 2019

Accepted: December 16, 2019

Published: December 19, 2019

Copyright $\odot 2019$ by author(s) and Scientific Research Publishing Inc. This work is licensed under the Creative Commons Attribution International License (CC BY 4.0).

http://creativecommons.org/licenses/by/4.0/

\begin{abstract}
Among the plants used by Bulgarian plants traditional medicine is Clinopodium vulgare L. (Lamiaceae). The aim of this study is to identify natural substances like some flavanoids and phenolcarbonic acids discovered in the plant with another technic because of Phenol carbonic acids. Instrumentation: The chromatographic studies were performed on a liquid chromatography. The identification of the components was carried out according to the spectral modifications after addition of the reagents of standard shifts. The results presented in this report seemed appropriate for the identification of flavonoids and phenol carbonic acids in extracts of Clinopodium vulgare.
\end{abstract}

\section{Keywords}

Clinopodium vulgare L., Phenolcarbonic Acids, Flavonoids, Chromatography

\section{Introduction}

Among the plants used by Bulgarian plants traditional medicine is Clinopodium vulgare L. (Lamiaceae) [1]. It has been used for the treatment of various skin diseases (topical application) and inflammations and for metabolism improvement in the form of decocting (oral application), for the healing of wounds and the treatment of wounds to viral infection, extracted from its skin extract and its metabolism. It is recommended for anti tumor treatment [2].

Phytochemical studies of the Clinopodium vulgare species were carried out by different authors and the presence of iridoids [3] [4], terpenoids [5] [6], fatty acids [7] [8] and triterpenes [9] has been proven. For to do that, various analyti- 
cal techniques have been proposed for the determination: layer chromatography, liquid chromatography [10] [11]. The aim of this study is to identify natural substances like some flavanoids and phenolcarbonic acids discovered in the plant with another technic because of phenol carbonic acids. They have the most important role in the stability of the plants in cases of unfavourable. It's a biologically active substance belongs to the group of phenolic compounds. Also in this plant, some authors have discovered the phenol carbonic acids. The necessity of that identification was that the phenolcarbonic acids possess bacteriostatic properties and it can suppress the ferments oxidizing activity. In this work, it was aimed to identify and determine the proportion of phenol carbonic acid and flavanoids in Clinopodium vulgare L., and if for this identification, the HLPC method is appropriated for this natural substance.

\section{Material and Methods}

\subsection{Material}

During the flowering of the plant, we collected ground parts including leaves of Clinopodium vulgare L. It is a Bulgarian medicinal plant well known. The Clinopodium vulgare $\mathrm{L}$. is one of the branches of the family Clinopodium Lamiaceae (Labiatae). It is a perennial herb erected up to $45 \mathrm{~cm}$ [12]. It grows in dry, sandy soil in rare woods and among bushes situated at an altitude not exceeding $1700 \mathrm{~m}$ in Europe and Asia. The dried, packed in paper bags and kept in a cool, dark place until analysis.

\subsection{Method}

\section{- Instrumentation}

The chromatographic studies were performed on a liquid chromatography system PERKIN ELMER with a UV detector SPD-2A and a sample introduction device SIL-A. A Merck analytical column LiChroCART $125 \times 4 \mathrm{~mm}$ with LiChrospher $(5 \mu \mathrm{m})$ and a Pell Ods $50 \times 2 \mathrm{~mm}$ protective guard column packed with 30 - $38 \mu \mathrm{g}$ CO (WATMAN, England) has been used with the system. A number extract Clinopodium vulgare and solid fractions were filtered separately through prior to injection syringes at the column. The conditions for analysis by HPLC were: Flow rate $1.2 \mathrm{ml} / \mathrm{min}$; Temperature: $20^{\circ}$ Detection $288 \mathrm{~nm} ; 20 \mu \mathrm{L}$ sample; 20 min time of execution; mobile application $\mathrm{A}-$ methanol: water/8.92 (v/v) B-methanol: water/45; 55 (v/v) (Table 1).

\section{- Reagents}

The reagents of the highest purity (>99.95), the HPLC-grade methanol and the reference standards CARL ROTH available were used throughout this study. The measurements were carried out immediately after the preparation of our extract.

\section{- UV/VIS spectral analysis}

The UV/VIS spectra of the isolated flavonoids constituents were recorded in methanol using the Perkin-Elmer UV/VIS spectrometer, Lambda 16 model. The 
Table 1. Analysis conditions.

\begin{tabular}{cc}
\hline Analysis Conditions & \\
\hline Ph mobile app & A-methanol: water/8.92 (v/v) \\
& B-methanol: water $/ 45.55(\mathrm{v} / \mathrm{v})$ \\
& $0-2020 \% \mathrm{~A}+80 \% \mathrm{~B}$ \\
Gradient program & $20-3515 \% \mathrm{~A}+85 \% \mathrm{~B}$ \\
& $35-4510 \% \mathrm{~A}+90 \% \mathrm{~B}$ \\
Flow rate & $45-500 \% \mathrm{~A}+100 \% \mathrm{~B}$ \\
Temperature & $1.2 \mathrm{ml} / \mathrm{min}$ \\
Detection & $20^{\circ} \mathrm{C}$ \\
& Using UV at $288 \mathrm{~nm}$ \\
\hline
\end{tabular}

identification of the components was carried out according to the spectral modifications after addition of the reagents of standard shifts $\left(\mathrm{NaMeO}, \mathrm{AlCl}_{3}\right.$, $\mathrm{AlCl}_{3} / \mathrm{HCl}, \mathrm{NaCH}_{3} \mathrm{COO}$ and $\mathrm{NaCH}_{3} \mathrm{COO} / \mathrm{H}_{3}$.

\section{- Sample preparation}

We conducted by grinding and filtration of Clinopodium. Indeed, $0.5 \mathrm{~g}$ of the above ground part of the plant were ground and then placed in the flask provided with the inverted water cooler and were extracted 3 times with $100 \mathrm{~mL}$ of petroleumether in a water bath. The duration of each extraction was 30 minutes. The petroleumether extracts were then filtered. The remaining material was again extracted 3 times with $100 \mathrm{ml}$ of chloroform for 30 minutes in a stoppered flask with an inverted water cooler and the chloroform extracts were filtered.

The remaining material was then extracted 3 times with $100 \mathrm{~mL}$ of methanol for 30 minutes in a capped flask with an inverted water cooler in a water bath. The combined methanol extracts were evaporated in vacuo to about $10 \mathrm{~mL}$ and quantitatively transferred to a $25.0 \mathrm{~mL}$ volumetric flask after adjustment with methanol. Acidic hydrolysis of $15 \mathrm{ml}$ of this extract was carried out by adding 15 $\mathrm{ml}$ of $5 \mathrm{M}$ hydrochloric acid and heating in a flask fitted with an inverted water chiller in a water bath for 9 hours.

After cloning with ammonia to obtain a $\mathrm{pH}=8$ and extraction 4 times with 25 $\mathrm{mL}$ of ethylacetate, the combined ethylacetate extracts were evaporated to obtain a dry residue. The latter was dissolved in methanol without water in a $25.0 \mathrm{~mL}$ volumetric flask and adjusted with the same solvent.

The standard solution was prepared as a methanol-based mixture containing $0.005 \%$ of each of the following 12 reference standards: chlorogenicacid, kaffeienic, hyperosid, rutin (quercelin, luteolin, kempferol, apigenin and acacetin).

\section{Results and Discussion}

The sample and the standard solution were analyzed separately using the me- 
thod described above from the standard mixture solution and the total extracted Clinopodium vulgare. The identification was carried out taking into account the total extract retention times (Table 3) compared to those of the standard mixture solution (Table 2). Our studies have shown that the method described exhibited good reproducibility. The results presented in this report proved seemed appropriate for the identification of flavonoids and phénol carbonic acids in extracts of Clinopodium vulgare. Opposed of the screening showed that GC it was an impractical technique for the analysis of clinically extractable components of Clinopodium vulgare L. The compounds of Table 3 can be found as free ingredients liberty [13]. Our work is called preliminary because thus, the quantification of the identified compounds is complicated because of the variety of possibilities unknown derivatives active compound compounds and conjugated forms. These results are comparable to the study carried out by bardarov for the study of the chemical composition of clinopodium vulgare $\mathrm{L}$. The method developed for HPLC fingerprints provided a quick analysis of the crude extracts of both species. The compounds were identified by comparison with the chromatogram of the five reference standards obtained under the specified experimental conditions. This method allowed by its speed and precision to separate the two molecules flavanoids and phenol carboni acid. The main flavonoid content from the leaves and stems of Rhododendron adamsii R. has also been determined quantitatively by HPLC. According to HPLC, Quercetin dominated the flavonoids (Table 3) in Clinopodium vulgare L. While in Rhododendron adamsii this is the myricetin (about $1.7 \%$ by weight) dominated the native flavonoids found in the leaves and stems [14].

Table 2. Sample-standard mixtures solution.

\begin{tabular}{|c|c|c|c|c|}
\hline $\begin{array}{l}\text { Retention time } \\
\text { in min (RT) }\end{array}$ & Area & $\begin{array}{c}\text { Relative retention } \\
\text { time RT }\end{array}$ & vs & Name \\
\hline 20.03 & 0.5869 & 0.394 & 4.3787 & Chlorogenic acid \\
\hline 21.04 & January 2965 & 0.414 & 9.6723 & Kafainic acid \\
\hline 27.90 & 1.9886 & 0.549 & 14.8351 & P. cumarinic acid \\
\hline 30.78 & 1.3980 & 0.505 & 10.4290 & Faurulic acid \\
\hline 39.33 & 0.4998 & 0.775 & 3.7285 & Hesperidin \\
\hline 39.99 & 0.9436 & 0.788 & 7.0398 & Hyperosid \\
\hline 40.59 & 1.2752 & 0.799 & 9.5129 & Rutin \\
\hline 48.93 & 0.9626 & 0.954 & 7.1812 & Quercelin \\
\hline 50.74 & 0.8450 & 1.000 & 6.3038 & Luteolin \\
\hline 52.94 & 0.7538 & 1.043 & 5.6233 & Kempferol \\
\hline 53.73 & 1.5258 & 1.058 & 11.3827 & Apigenin \\
\hline 59.78 & 1.2089 & 1.178 & 9.0185 & Acacetine \\
\hline
\end{tabular}


Table 3. Extracts of Clinopodium vulgare.

\begin{tabular}{ccccc}
\hline Retention time in min (RT) & Area & Relative retention time & Concentration & Name \\
\hline 19.92 & 0.0487 & 0.3227 & 0.3227 & Chlorogenic acid \\
21.30 & 0.0386 & 0.2572 & 0.2573 & Kafainic acid \\
28.77 & 0.1050 & 0.5950 & 0.5950 & P. cumarinic acid \\
30.29 & 0.0892 & 0.5508 & 0.5908 & Faurulic acid \\
39.49 & 0.0754 & 0.4995 & 0.4996 & Mesperidin \\
40.45 & 0.3642 & 2.4105 & 2.4105 & Hyper \\
41.41 & 0.6164 & 4.0802 & 4.0803 & Rutin \\
49.38 & 2.4792 & 16.4094 & 16.4094 & Quercetin \\
51.17 & 0.5447 & 3.6057 & 3.6057 & Luteolin \\
52.03 & 0.5458 & 4.2748 & 4.2748 & Kempterol \\
52.74 & 0.5577 & 3.6915 & 3.6915 & Apigemin \\
59.75 & 0.3037 & 1.176 & 2.0101 & Accatin \\
\hline
\end{tabular}

\section{Conclusion}

In the end, our work has made it possible to isolate the substances found by other authors in the Bulgarian species, proving that the HLPC method remains a reference in terms of identifying the constituents of flavonoids. Our studies have shown that the method described exhibited good reproducibility and seemed appropriate for the identification of flavonoids and phenolcarbonic acids in extracts of Clinopodium vulgare.

\section{Conflicts of Interest}

The authors declare no conflicts of interest regarding the publication of this paper.

\section{References}

[1] Obreshkova, D., Naidenova, E. and Mokoko, J.B. (1991) Problemina Farmacolgiataifarmaciata. Reports of the Bulgarian Academy of Science, 4, 119. (In Bulgaria)

[2] Obreshkova, D., Naidenova, E., Angelov, I. and Koleva, V. (1993) Phyto-Chemical and Tox-icological Research of Triterpene Mixture Derived from the Species Clinopodium vulgare L. Reports of the Bulgarian Academy of Science, 46, 119.

[3] Kiehne, A. and Engelhardt, U. (1996). Thermospray-LC-MS Analysis of Various Groups of Polyphenols in Tea. Zeitschrift für Lebensmittel-Untersuchung und Forschung, 202, 48-54. https://doi.org/10.1007/BF01229684

[4] Bianco, A. and Passacantilli, P. (1984) Iridoid Glucosides from Satureja vulgaris. Phytochemistry, 23, 121-123. https://doi.org/10.1016/0031-9422(84)83089-7

[5] Popa, D.P. and Pisechnik, T.S. (1974) Analiz lekarstvennykh rasteniy. Himiya Prirodnyn Soedimimii, No. 4, 529-530. (In Russian)

[6] Popa, D.P. and Orglyan, T.M. (1976) Rastitelnye Resoury. Himiya Prirodnyn Soe- 
dimimii, 12, 247-252.

[7] Kostka, B. (1969) Analyse phytochimique de l'herbe Clinopodium vulgare L. (Lamiaceae). Acta Poloniae Pharmaceutica, 26, 387.

[8] Broda, B. and Krolikowaka, M. (1974) Phytochemical Analysis of the Clinopodium vulgare L. (Labiatae) Herb. II. Components of the Alcoholic Extract-Saponins and Triterpenes. Acta Poloniae Pharmaceutica, 31, 213-220.

[9] Broda, B. and Krolikowaka, M. (1974) Phytochemical Analysis of the Clinopodium vulgare L. (Labiatae) Herb. III. Components of the Alcoholic Extract-Saponins and Triterpenes. Acta Poloniae Pharmaceutica, 31, 373-378.

[10] Heing, W. and Wicht, M. (1990) Österreichische Apotheker-Zeitung. Deutsche Apotheker Zeifung, No. 38, 2058-2062.

[11] Lamaison, J.L. and Carnat, A. (1990) The Amount of Main Flavonoids in Flowers and Leaves of Crataegus Monogyna Jacq. and Crataegus Laevigata (Poiret) DC. (Rosacea). Pharmaceutica Acta Helvetiae, 65, 315-320.

[12] Hiermann, A. and Kartnig, T. (1984) The HPLC Fingerprint Analysis Can Be Used for Qualitative Analysis, Especially to Control Identity of Plant Materiali. Scientia Pharmaceutica, 52, 30.

[13] Mitkov, S., Obrehkova, D., Ilieva, I., Pangarova, T. and Pencheva, I. (2002) Phenolcarboxylic Acids in Echium Vulgare L. Acta Pharmaceutica Turcica, 44, 43-48.

[14] Stefanovic, O. (2011) In Vitro Antibacterial Efficacy of Clinopodium vulgare L. Extracts and Their Synergistic Interaction with Antibiotics. Journal of Medicinal Plants Research, 5, 4074-4079. 